\title{
Antiproliferative Activity of Allelochemicals Present in Aqueous Extract of Synedrella nodiflora (L.) Gaertn. In Apical Meristems and Wistar Rat Bone Marrow Cells
}

\author{
Sanjib Ray*1, Saumabha Chatterjee ${ }^{1}$ and Chandra Sekhar Chakrabarti ${ }^{1}$ \\ ${ }^{1}$ Molecular Biology and Genetics Unit, Department of Zoology, The University of Burdwan, Golapbag, \\ Burdwan-713104, West Bengal, India.
}

\begin{abstract}
Synedrella nodiflora (L.) Gaertn. is a kind of weed with ethno medicinal uses. Here, we aimed to evaluate the antiproliferative activity of AESN (aerial parts aqueous extract of S. nodiflora) in root and shoot apical meristems and WRBMCs (Wistar rat bone marrow cells). The phytotoxic and antiproliferative activities of AESN were evaluated using green-gram seedlings and onion roots. The AESN induced cell cycle delay was analysed by scoring mitotic index, interphase cell frequency, prophase-metaphase and anaphase-telophase cumulative frequency in onion apical meristem cells and by analysing metaphase frequency in WRBMCs. The AESN treatment showed dose dependent root and shoot growth retardation and reduced number of branch root sprouting in green-gram seedlings. Half maximal growth inhibitory concentration (IC $\left.C_{50}\right)$ of AESN was 0.4 $\mathrm{mg} / \mathrm{ml}$ at $48 \mathrm{~h}$ in onion. The mitotic index percentage significantly reduced (44.9 and $62.7 \%$ respectively for 0.5 and $2 \mathrm{mg} / \mathrm{ml}$ AESN cells at $48 \mathrm{~h}$ ), interphase and prophase-metaphase cumulative frequency increased and anaphase-telophase cumulative frequency decreased in AESN treated onion root tip cells indicating an overall antiproliferative activity. In WRBMCs, AESN treatment could induce significant ( $p<0.001)$ mitodepression $(80.6 \%$ decreased metaphase frequency with $500 \mathrm{mg} / \mathrm{kg}$ body weight for $15 \mathrm{~h}$ ). These mitostatic activities of AESN may be due to the actions of allelochemicals. It may be said that the AESN contains antiproliferative active principle(s) that could induce significant delay in cell cycle kinetics in apical meristems and WRBMCs.
\end{abstract}

Key Words: Allium cepa, Mitodepression, Mitotic index, Phenolic compounds, Phytochemicals.

\section{INTRODUCTION}

Cancer is an important global health crisis and the antiproliferative pharmacological activities of plant derived secondary metabolites appear to elucidate the chemo-preventive or anticancer effects ${ }^{[1]}$. Some of the effective anticancer and anti-neoplastic agents target on the cell cycle progression machinery ${ }^{[2]}$. Paclitaxel $\left(\right.$ Taxol$\left.^{\circledR}\right)$ is an important plant derived drug used in the treatment of cancer. Paclitaxel arrests the cell cycle in $\mathrm{G}_{2} / \mathrm{M}$ phase transition ${ }^{[3]}$. Many plant derived active principles act as antitumor and apoptotic inducer in cancer cells ${ }^{[4]}$. The discovery of effective anticancer agents like vinblastin and vincristine isolated from Catharanthus roseous and Paclitaxel $\left(\right.$ Taxol $\left.^{\circledR}\right)$ from Taxus brevifolia provide convincing evidence that plants are a source of novel anticancer chemotherapeutic agents ${ }^{[5]}$. Therefore, renewed interest exists to explore the efficient antiproliferative agents from the natural products of plant origin.

Synedrella nodiflora (L.) Gaertn. (Family: Asteraceae) is a small annual flowering weed. It is a native plant of tropical America and also found in India, Bangladesh, Malaysia, Japan, China and other Indopacific countries. In India, the leaves of S. nodiflora are traditionally used for the treatment of rheumatism. In Malaysia, it is used as an external medicine to cure inflammation, headache and earache. In Ghana, hot aqueous extract of this plant is given orally for treating epilepsy. The leaves are also used to treat hiccup and stomachache and in threatened abortion cases ${ }^{[6-9]}$. The phytochemical profile indicates the presence of alkaloids, flavonoids, triterpenes, saponins, simple phenolics and polyoses in the various solvent extracts of $S$. nodiflor ${ }^{[9]}$. Recently the toxicological ${ }^{[10],[11]}$, insecticidal ${ }^{[7]}$, larvicidal ${ }^{[12]}$, antibacterial, antioxidant ${ }^{[13]}$, antidiarrhoeal, hypoglycaemic ${ }^{[14]}$ and anti-inflammatory properties $^{[15]}$ of this plant has been reported. However, antiproliferative potential of AESN (aerial parts aqueous extracts of S. nodiflora) is not yet known. Therefore in the present study, antiproliferative activity of AESN was analysed using both plant and animal systems. Moreover, the secondary metabolites present in AESN were qualitatively detected and the total phenol and tannin contents were measured.

Correspondence: Sanjib Ray, Molecular Biology and Genetics Unit, Department of Zoology, The University of Burdwan, Golapbag, Burdwan713104, West Bengal, India. Tel.: 9134 22656566; Fax: 9134 22530452; E-mail:ray.sanjibray@gmail.com 


\section{MATERIALS AND METHODS}

2.1. Chemicals

Colchicine, methanol, glacial acetic acid and orcein were obtained from BDH chemicals Ltd., Poole Dorset, UK. Folin-Ciocalteu's phenol reagent was obtained from MERCK Specialities Pvt. Ltd., Mumbai, India. Polyvinylpyrrolidone (K-30) was purchased from SRL Pvt. Ltd., Mumbai, India. Tannic acid powder obtained from HIMEDIA Laboratories Pvt. Ltd., Mumbai, India. Other chemicals used in the study were of analytical grade from reputed manufacturers.

\subsection{Plant products collection, storage and extract preparation}

Fresh aerial parts of $S$. nodiflora were collected from The Burdwan University Golapbag campus, West Bengal, India in November, 2011. This plant species was taxonomically identified by Dr. Ambarish Mukherjee (Taxonomist), Professor, Department of Botany, The University of Burdwan. The voucher specimen (No.BUGBSC013) is maintained in the department for future reference.

Collected aerial parts of $S$. nodiflora were washed in tap water, shade dried, directly crushed into small pieces and followed to pulverize using electric grinder (Philips Mixer Grinder HL1605, Kolkata, West Bengal, India). Ground aerial part powder was then stored in an air tight container for future use. Dried,powdered, plant material $(50 \mathrm{~g})$ was extracted in $500 \mathrm{ml}$ of boiling distilled water in water bath for $30 \mathrm{~min}$. At the end it was filtered through Whatman filter paper No. 1 (Sigma-Aldrich, Inc., St. Louis, MO, USA). The extract was stored at $-20^{\circ} \mathrm{C}$ for further use. For determination of extract concentration $(11.3 \mathrm{mg} / \mathrm{ml})$ and extract value $(17.64 \%$ $\mathrm{w} / \mathrm{w}), 10 \mathrm{ml}$ of extract was evaporated to complete dryness in the hot air oven at $60{ }^{\circ} \mathrm{C}$.

\subsection{Experimental plants}

Green-gram (Vigna radiata) seedlings and onion (Allium cepa) root apical meristems were used for morphometric bioassay for antiproliferative and phytotoxic activities. The mitotic index and mitotic cells phase frequencies were scored in onion root apical meristem cells.

\subsection{Experimental animals}

Male Wistar-albino rats, aged 4-6 weeks and weighing 40-60 g, were collected from local suppliers and maintained in the Departmental animal house in community cages at room temperature, with controlled lighting (12 h light:12 h dark). Standard rat diet and water ad libitum were used in all experiments. The rules of the "Institutional Animal Care and Use Committee" were strictly followed during the whole experiment and steps were taken to protect the welfare of the experimental animals. The influence of AESN on the cell cycle kinetics was analyzed in WRBMCs arresting cells at metaphase with colchicine.

\subsection{Root and shoot growth retardation and branch root sprouting inhibition in green gram seedlings}

2.5.1 Culture and treatment of green-gram seedlings

Green-gram seeds were surface sterilized with $1 \%$ sodium hypochlorite solution, and allowed to germinate in the dark on wet filter paper in glass Petri dishes containing five different concentrations, $0,0.5,1$, 2,4 and $6 \mathrm{mg} / \mathrm{ml}$, of AESN and both the root and shoot length of seedlings were measured on the $5^{\text {th }}$ day and at the same time the branch root numbers were counted. Three replicas of each with 10 seeds were prepared for each treatment. Petri dishes containing distilled water were considered as control.

\subsection{Root growth retardation in onion}

\subsubsection{Culture and treatment of onion roots}

Similar sized onion bulbs were purchased from local market, old root and dry skin removed, washed thoroughly in tap water and allowed for root sprouting in test tube containing distilled water in dark culture room where temperature maintained at $25^{\circ} \mathrm{C}$. For dose dependent root growth inhibition pattern analysis, $24 \mathrm{~h}$ aged onion roots (0.6-0.8 cm initial length) were exposed with 5 different concentrations, $0,0.5,1,2,4$ and 6 $\mathrm{mg} / \mathrm{ml}$, of AESN for 24 and $48 \mathrm{~h}$ and at the end of treatment root lengths were measured and the growth retardation percentages were calculated.

\subsection{Mitotic index reduction and alteration in mitotic cell phase frequency}

\subsubsection{Treatment and preparation of mitotic phases from onion root meristem cells}

For antiproliferative assay, the $48 \mathrm{~h}$ aged onion root meristem cells were exposed with 2 different doses $(0.5$ and $2 \mathrm{mg} / \mathrm{ml})$ of AESN for 4, 6, 8, 24 and $48 \mathrm{~h}$. The control group, which had not received treatment, was maintained in distilled water. For evaluation of the antiproliferative effects of AESN, the procedure as described by Greice et. al. ${ }^{[16]}$ was followed with slight modifications. The cells were fixed in aceto-methanol (3 parts methanol : 1 part glacial acetic acid) for $24 \mathrm{~h}$ and hydrolyzed for $10 \mathrm{~min}$ in $1 \mathrm{~N} \mathrm{HCl}$ at $60{ }^{\circ} \mathrm{C}$, stained with $2 \%$ aceto-orcein and squashed in $45 \%$ acetic acid for each treatment ${ }^{[17]}$. Slides were randomly coded and for each set of experiment at least five slides were studied, with 40X objective lens, under bright field light microscope, 
Leica DM LB2 (Leica Microsystems Wetzlar GmbH, Wetzlar, Germany) with digital camera and computer attachment for photomicrography, and a minimum of 1000 cells were scored from each set.

\subsection{Cell cycle delay in Wistar rat bone marrow cells}

\subsubsection{Treatment and preparation of metaphases}

The AESN was injected into intraperitoneal cavity of albino rats. An equal volume of double distilled water was injected to the control rats group. At each data point, six rats and three different doses $(100,300$ and $500 \mathrm{mg} / \mathrm{kg}$ body weight) were used. Cells were fixed at $15 \mathrm{~h}$ after AESN treatment and each preceded by $3 \mathrm{~h}$ colchicine $(10 \mathrm{mg} / \mathrm{kg}$ body weight $)$ treatment. The untreated and AESN treated animals were sacrificed by cervical dislocation. The femur bones were dissected out and the bone marrow cells were obtained in glass centrifuge tube by injecting $2.5 \mathrm{ml}$ of $0.56 \% \mathrm{KCl}$ (hypotonic solution, pre-warmed at $37^{\circ} \mathrm{C}$ ). Cells were given hypotonic treatment for $30 \mathrm{~min}$ at $37^{\circ} \mathrm{C}$ in water bath and were fixed in acetic acid and methanol (1:3). Slides were prepared by flame-drying method, stained in $2 \%$ Giemsa for $35 \mathrm{~min}$ and mounted in synthetic medium.

\subsection{Phytochemicals detection}

The AESN was tested to identify alkaloids, flavonoids, anthraquinones, terpenoids, steroids, tannins, phlobatannins, saponins, glycosides and carbohydrates following standard procedures as described by Trease and Evans ${ }^{[18]}$, Sofowara ${ }^{[19]}$ and Harborne ${ }^{[20]}$ with slight modifications, briefly as follows.

\subsubsection{Tests for alkaloids}

Aqueous extract was acidified with few drops of glacial acetic acid and tested for the presence of alkaloids. A few drops of Mayer's reagent $\left(1.36 \mathrm{~g}\right.$ of $\mathrm{HgCl}_{2}$ and $5 \mathrm{~g}$ of $\mathrm{KI}$ in $100 \mathrm{ml}$ distilled water) was added to $1 \mathrm{ml}$ of acidified extract, formation of white or pale yellow precipitate indicates the presence of alkaloids (Mayer's test). A few drops of Wagner's reagent (Solution of iodine in potassium iodide), was added to $1 \mathrm{ml}$ of acidified extract and appearance of a reddish brown precipitate, indicate the presence of alkaloids (Wagner's test). Acidified extracts gave yellow colour precipitate with Hager's reagent, saturated solution of Picric acid, (Hager's test) and with $10 \%$ tannic acid solution gave buff colour precipitate (Tannic acid test) indicating alkaloids are present.

\subsubsection{Tests for flavonoids}

In $1 \mathrm{ml}$ of extract 10-20 drops of diluted $\mathrm{HCl}$ was added, followed by a small piece of zinc. Creation of pink or reddish pink colour precipitate indicates the presence of flavonoids (Zinc hydrochloride test). In $1 \mathrm{ml}$ of extract a few magnesium turnings were added and then drop by drop concentrated $\mathrm{HCl}$ was added. Creation of pink scarlet or green to blue colour after a few minutes indicates the presence of flavonoids (Shinoda test). In 1 $\mathrm{ml}$ of extract few drops of sodium hydroxide solution was added, an intense yellow colour formed which turned to colourless after addition of few drops of diluted $\mathrm{HCl}$, indicates the presence of flavonoids (Alkaline reagent test). Methanol $(50 \%)$ solution of volume $1.5 \mathrm{ml}$ was mixed with $4 \mathrm{ml}$ of extract and then the mixture was warmed, few metal magnesium turnings were added and 5-6 drops of concentrated hydrochloric acid was added. The appearance of red colour indicates the presence of flavonoids ${ }^{[21]}$.

\subsubsection{Test for anthraquinones}

Benzene ( $2 \mathrm{ml}$ ) was mixed properly with $2 \mathrm{ml}$ of aqueous extract, filtered and $3.5 \mathrm{ml}$ of $10 \%$ ammonia solution was added to the filtrate. The mixture was shaken and the absence of pink, red or violet colour in the lower phase indicates the absence of free anthraquinone (Borntrager's test).

\subsection{4. $T$ ests for terpenoids and steroids}

To test terpenoids and steroids the procedures as described by Kantamreddi $e$ t. al. ${ }^{[22]}$ was followed with slight modifications. In brief, glacial acetic acid, $1 \mathrm{ml}$, was mixed with $1 \mathrm{ml}$ of aqueous extract and then $1 \mathrm{ml}$ of concentrated sulphuric acid was added through the wall of the test tube kept in ice flakes. Formations of brown and green colour indicate the presence of terpenoids and steroids respectively.

\subsubsection{Tests for tannins}

Few drops of $\mathrm{FeCl}_{3}$ were added to $2 \mathrm{ml}$ of aqueous extract and the formation of bluish black colour indicates the presence of tannins (Ferric chloride test). Few drops of bromine solution were added to $1 \mathrm{ml}$ of test extract, decolourization of the bromine water indicates the presence of tannins (Bromine water test). Few drops $\mathrm{NaOH}$ solution was added to $1 \mathrm{ml}$ of extract and the appearance of yellow to red precipitate within a short time indicate the presence of tannins (Alkaline reagent test). 


\subsubsection{Test for phlobatannins}

To test phlobatanin the procedure as described by Edeoga $e t . a l^{[23]}$ was followed with slight modification. In brief, the aqueous extract was boiled with $1 \mathrm{~N} \mathrm{HCl}$ and the appearance of red precipitate indicates presence of phlobatannins.

\subsubsection{Test for saponins}

Few drops of $\mathrm{NaHCO}_{3}$ was added to $5 \mathrm{ml}$ of aqueous extract and shaken vigorously and left for three minutes. Formation of honeycomb like stable froth indicates the presence of saponins (Foam test).

\subsubsection{Tests for glycosides}

Aqueous $\mathrm{NaOH}$ solution $(1 \mathrm{ml})$ was added to $1 \mathrm{ml}$ of extract and the absence of pale yellow precipitate indicates the absence of glycosides. Extract $(2 \mathrm{ml})$ was hydrolyzed with $\mathrm{HCl}$ solution and neutralized with $\mathrm{NaOH}$ solution and then a few drops of Fehling's A and B were added. The absence of red precipitate indicates the absence of glycosides (Fehling's test). Test solution when treated with bromine water gives yellow precipitate (Bromine water test).

\subsubsection{Test for carbohydrates}

Benedict's solution $(5 \mathrm{ml})$ was added to $0.5 \mathrm{ml}$ of extract and boiled for $5 \mathrm{~min}$. Absence of coloured precipitate indicates the absence of carbohydrates (Benedict's test). To test presence of reducing sugars, few drops of sample was added to equal volume of Fehling's A (Copper sulfate in distilled water) and Fehling's B (Potassium tartarate and Sodium hydroxide in distilled water) reagents and were mixed, boiled, and at the end the absence of brick red precipitate of cuprous oxide, indicate reducing sugars were absent (Fehling's test).

\subsection{Estimation of total phenol and tannin contents in AESN}

Total phenol and tannin contents in AESN were estimated according to the procedure of Makkar et. $a l .{ }^{[24]}$, with slight modification. Briefly, $10 \mu$ of AESN extract was taken in a test tube and volume was made to $1 \mathrm{ml}$ with distilled water. Then, $0.5 \mathrm{ml}$ Folin-Ciocalteu's phenol reagent $(1 \mathrm{~N})$ was added and mixed thoroughly. Then $2.5 \mathrm{ml} 20 \%$ Sodium carbonate solution $\left(25\right.$ gram of $\mathrm{Na}_{2} \mathrm{CO}_{3}, 10 \mathrm{H}_{2} \mathrm{O}$ was dissolved in distilled water and made the volume to $125 \mathrm{ml}$ with distilled water) was added and mixed properly and then it was kept for 40 minutes at room temperature $\left(25 \pm 2{ }^{\circ} \mathrm{C}\right)$. Optical density was recorded at $725 \mathrm{~nm}$ in UV-Vis spectrophotometer (UV-1800 Series, Shimadzu, Japan) and concentration was determined from the standard curve. The standard tannic acid solution was prepared for standard curve from the freshly prepared solution, $0.5 \mathrm{mg} / \mathrm{ml}$, of tannic acid (5 mg tannic acid powder was dissolved in $10 \mathrm{ml}$ of distilled water). Total phenol was estimated as tannic acid equivalent and expressed on dried matter basis.

Non-tannins phenol was estimated by precipitating tannins with polyvinyl polypyrrolidone (PVPP). PVPP (200 mg) was taken in test tube and then $2 \mathrm{ml}$ distilled water and $2 \mathrm{ml}$ AESN were added, vortexed and kept in refrigerator at $4{ }^{\circ} \mathrm{C}$ for 15 minutes. Then the mixture was again vortexed and filtered through Whatman filter paper No. 1. Filtrate was taken for estimation of non tannin phenol. Filtrate (10 $\mu$ l) was taken in test tube and volume was made to $1.0 \mathrm{ml}$ with distilled water and then processed like that of total phenol estimation. Concentration of non tannin phenol was calculated from the standard curve and expressed on dry matter basis. Total tannin content was calculated by subtracting non tannin phenol from total phenol.

\subsection{Scoring and statistical analysis.}

Green-gram seedling's root and shoot growth and onion root growth were recorded and the growth retardation percentages were calculated. The statistically significant difference between the control and treated groups for root/shoot length were analyzed using Student's t-test. Using Probit analysis ${ }^{[25]}$, $\mathrm{IC}_{50}$ was determined for green-gram root growth retardation with statistical software, SPSS version14.0 (SPSS Inc. Chicago, Illinois, USA). In onion root tip cells, the slides were randomly coded and for each set of experiment at least five slides were studied under bright field light microscope with 40x objective lens and a minimum of 1000 cells were scored. The mitotic index and cell phase frequencies were calculated. Cell division phases were scored on the basis of the nucleus and chromosomal characteristics. The cell cycle kinetics was determined by scoring mitotic index (MI), prophase-metaphase and anaphase-telophase cumulative index. MI was calculated as No. of cells in dividing phase / Total No. of cells counted X 100. Like Mitotic index, prophase-metaphase and anaphasetelophase cumulative indexes were calculated as No. of cells in that particular dividing phases / Total No. of dividing cells X 100. In WRBMCs, the slides were randomly coded and the patterns of cell cycle kinetics were determined by scoring of the metaphase frequency (MF), MF\%= Number of metaphases/Total number of cells scored X 100. The statistical significance of the difference between the control and treated groups for MI and 
cell phase frequency were analyzed using a $2 \mathrm{X} 2$ contingency $\chi 2$-test. Mean and standard error of mean (SEM) were calculated using Origin 50.

\section{RESULTS}

\subsection{Morphometric bioassay for phytotoxicity and antiproliferation}

\subsubsection{Root and shoot growth retardation and reduced branch root sprouting in green-gram seedlings}

Data clearly indicate that the AESN could induce dose dependent growth retardation of green-gram root and shoot. In the present study, the maximum root length $(4.13 \pm 0.23 \mathrm{~cm})$ was recorded from untreated groups while minimum root length $(0.95 \pm 0.15 \mathrm{~cm})$ was recorded from our highest concentration $(6 \mathrm{mg} / \mathrm{ml}) \mathrm{of}$ AESN. The root growth inhibition was calculated as 2, 19, 22, 47 and $77 \%$ for the AESN concentrations respectively of $0.5,1,2,4$ and $6 \mathrm{mg} / \mathrm{ml}$ at $120 \mathrm{~h}$. Like root growth inhibition, branch root sprouting reduced $(100 \%$ reduction at a concentration $6 \mathrm{mg} / \mathrm{ml})$ and shoot growth was also inhibited $(67 \%$ at a concentration 6 $\mathrm{mg} / \mathrm{ml}$ ) in dose dependent manner. $\mathrm{IC}_{50}$ values were calculated as $4.47,3.55$ and $2.82 \mathrm{mg} / \mathrm{ml}$ for root growth, shoot growth and branch root sprouting respectively (Table 1, Fig. 1). These results were analysed by comparing with untreated controls.

\subsubsection{Onion root growth retardation assay}

The AESN could induce dose dependent growth retardation of onion roots. The root growth inhibition was calculated as $65,83,87,91$ and $96 \%$ for the AESN concentrations of $0.5,1,2,4$ and $6 \mathrm{mg} / \mathrm{ml}$ respectively on the $2^{\text {nd }}$ day of treatment. $\mathrm{IC}_{50}$ for onion root growth was calculated as $0.4 \mathrm{mg} / \mathrm{ml}$ at the end of $48 \mathrm{~h}$ AESN treatment. In the present study, the maximum root length $(3.26 \pm 0.11 \mathrm{~cm})$ was recorded from the untreated groups of onion while minimum length $(0.71 \pm 0.06 \mathrm{~cm})$ was recorded from the highest concentration $(6 \mathrm{mg} / \mathrm{ml})$ of AESN on the $3^{\text {rd }}$ day (Fig.2, Table S1, Fig.3).

\subsection{Mitodepression assay for antiproliferation}

\subsubsection{Onion root apical meristem cells}

Data clearly indicate the tendency of mitodepression in AESN treated onion root meristem cells as compared to untreated controls. Dose dependent mitotic index depression phenomenon was observed in AESN treated samples. The significant $(p<0.01)$ differences in mitotic index was seen between treated and untreated root apical meristem cells. In the present study the maximum reduction in mitotic index percentage $(62.7 \%)$ was calculated in AESN treated, $2 \mathrm{mg} / \mathrm{ml}$ for $48 \mathrm{~h}$. Prophase-metaphase and anaphase-telophase cumulative index ratios were 58/42, 67/33, 80/20 respectively with concentrations $0,0.5$ and $2 \mathrm{mg} / \mathrm{ml}$ of AESN treated for $8 \mathrm{~h}$. More or less similar patterns of dose dependent increased prophase-metaphase and anaphase-telophase index ratios were also observed at 24 and $48 \mathrm{~h}$ of AESN treatment (Table 2).

\subsubsection{Wistar rat bone marrow cells}

Data indicate AESN could induce dose dependent decreased metaphase frequency percentage in WRBMCs. Three hours colchicine $(10 \mathrm{mg} / \mathrm{kg})$ treatment could arrest cells at metaphase $(4.32 \pm 0.72)$ and this metaphase frequency significantly $(\mathrm{p}<0.001)$ reduced in all the AESN treated groups of rats. The metaphase frequency reduced 50.7, 73.2 and $80.6 \%$ in the AESN treated groups for 100, 300 and $500 \mathrm{mg} / \mathrm{kg}$ body weight, respectively as compared to untreated controls (Table 3 ).

Table 1. Effect of AESN on root and shoot growth and branch root sprouting of Vigna radiata at $120 \mathrm{~h}$ treatment.

\begin{tabular}{|c|c|c|c|c|c|c|}
\hline \multirow{2}{*}{$\begin{array}{c}\text { Dose } \\
(\mathrm{mg} / \mathrm{ml})\end{array}$} & \multicolumn{2}{|c|}{ Root length $(\mathrm{cm})$} & \multicolumn{2}{|c|}{ Shoot length $(\mathrm{cm})$} & \multicolumn{2}{|c|}{ Branch root \#/Seedling } \\
\hline & Range & $\begin{array}{c}\text { Mean } \pm \text { SEM } \\
\text { (Reduction \%) }\end{array}$ & Range & $\begin{array}{c}\text { Mean } \pm \text { SEM } \\
\text { (Reduction \%) }\end{array}$ & Range & $\begin{array}{c}\text { Mean } \pm \text { SEM } \\
\text { (Reduction \%) }\end{array}$ \\
\hline 0.0 & $3.0-5.2$ & $4.13 \pm 0.23 \quad(00)$ & $7.0-8.8$ & $7.81 \pm 0.18(00)$ & $4-8$ & $5.6 \pm 0.34(00)$ \\
\hline 0.5 & $2.5-4.9$ & $4.06 \pm 0.24 \quad(02)$ & $5.8-8.9$ & $7.71 \pm 0.35$ & $3-7$ & $5.2 \pm 0.40(07)$ \\
\hline 1.0 & $2.3-4.8$ & $3.34 \pm 0.26^{\mathrm{b}}(19)$ & $4.3-8.0$ & $6.18 \pm 0.38^{\mathrm{a}}(21)$ & $1-7$ & $4.0 \pm 0.56^{\mathrm{b}}(29)$ \\
\hline 2.0 & $2.0-4.4$ & $3.22 \pm 0.29^{\mathrm{b}}(22)$ & $3.6-7.3$ & $5.70 \pm 0.32^{\mathrm{a}}(27)$ & $1-6$ & $3.8 \pm 0.47^{\mathrm{b}}(32)$ \\
\hline 4.0 & $1.1-3.4$ & $2.21 \pm 0.24^{\mathrm{a}}(47)$ & $2.0-5.0$ & $3.56 \pm 0.28^{\mathrm{a}}(54)$ & $0-4$ & $1.6 \pm 0.48^{\mathrm{a}}(71)$ \\
\hline 6.0 & $0.3-1.7$ & $0.95 \pm 0.15^{\mathrm{a}}(77)$ & $1.3-3.5$ & $2.59 \pm 0.23^{\mathrm{a}}(67)$ & $0-0$ & $0.0 \pm 0.00^{\mathrm{a}}(100)$ \\
\hline $\mathrm{IC}_{50}$ & & $4.47 \mathrm{mg} / \mathrm{ml}$ & & $3.55 \mathrm{mg} / \mathrm{ml}$ & & $2.82 \mathrm{mg} / \mathrm{ml}$ \\
\hline
\end{tabular}

${ }^{\mathrm{a}}$ Significant at $p<0.001,{ }^{\mathrm{b}}$ at $p<0.05$ with Student's t- test. \#; number, SEM; Standard error of mean. 


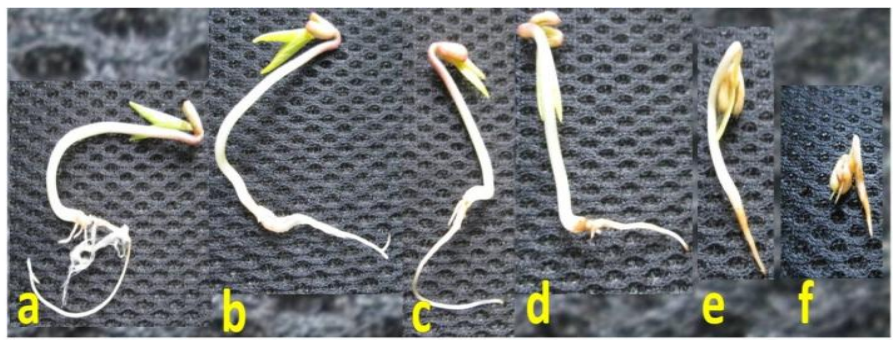

Figure 1. Photograph showing influence of AESN on root and shoot growth and branch root sprouting at $48 \mathrm{~h}$ of treatment where $\mathrm{a}, \mathrm{b}, \mathrm{c}, \mathrm{d}$, e and f denote AESN concentrations of $0,0.5,1,2,4$ and $6 \mathrm{mg} / \mathrm{ml}$ respectively.

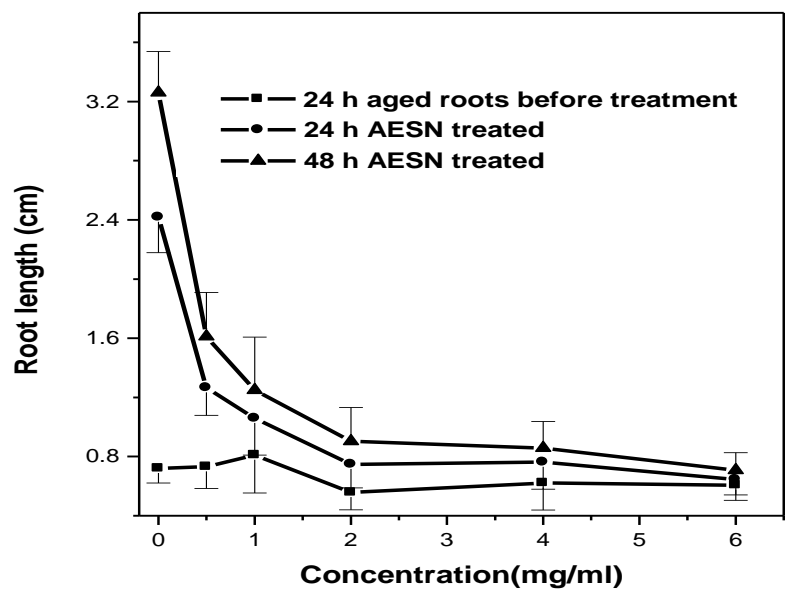

Figure 2. Dose dependent growth retardation effects of AESN on onion roots. Each data point is the mean root length of 35-40 roots.
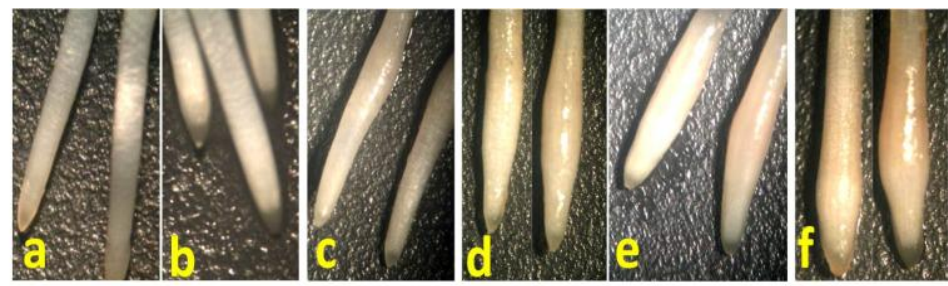

Figure 3. Photomicrograph showing AESN induced root apical meristem growth retardation and swelling patterns at $48 \mathrm{~h}$ of treatment where a, b, c, d, e and f denote AESN concentrations of $0,0.5,1,2,4 \mathrm{and} 6 \mathrm{mg} / \mathrm{ml}$ respectively.

\subsection{Preliminary phytochemical detections}

Preliminary phytochemical analysis revealed that AESN possess alkaloids, flavonoids, terpenoids, tannins, phlobatannins and saponins while anthraquinones, steroids, glycosides and carbohydrates were absent (Table 4).

\subsection{Estimation of total phenol and tannin contents in AESN}

Total phenol and tannin contents were found to be $1.16 \pm 0.1$ and $0.49 \pm 0.1 \mathrm{~g} \%$ tannic acid equivalent in dried powdered plant material respectively. 
Table 2. Mitotic index percentage, prophase-metaphase and anaphase-telophase cumulative frequency alteration in root apical meristem cells after treatment with the AESN

\begin{tabular}{llllllllc}
\hline $\mathrm{H}$ & $\begin{array}{l}\text { Conc. } \\
\mathrm{mg} / \mathrm{ml}\end{array}$ & TC & IN & $\sum$ DC & MISEM (Reduction \%) & \multicolumn{2}{c}{$\begin{array}{c}\text { Cells percentage } \\
\text { P+M }\end{array}$} \\
\hline 4 & 0.0 & 1878 & 1779 & 099 & $5.27 \pm 0.42$ & & $67 \pm 4.6$ & $33 \pm 4.6$ \\
& 0.5 & 1681 & 1627 & 054 & $3.21 \pm 0.24^{\mathrm{b}}$ & $(39)$ & $85 \pm 2.8$ & $15 \pm 2.8$ \\
& 2.0 & 1924 & 1867 & 057 & $2.96 \pm 0.16^{\mathrm{a}}$ & $(44)$ & $86 \pm 1.6$ & $14 \pm 1.6$ \\
6 & 0.0 & 3147 & 3030 & 117 & $3.72 \pm 0.26$ & & $64 \pm 2.5$ & $36 \pm 2.5$ \\
& 0.5 & 2608 & 2553 & 55 & $2.11 \pm 0.12^{\mathrm{a}}$ & $(43)$ & $75 \pm 4.8$ & $25 \pm 4.8$ \\
& 2.0 & 2243 & 2218 & 25 & $1.12 \pm 0.34^{\mathrm{a}}$ & $(70)$ & $84 \pm 0.4$ & $16 \pm 0.4$ \\
8 & 0.0 & 2942 & 2845 & 097 & $3.30 \pm 0.35$ & & $58 \pm 3.4$ & $42 \pm 3.4$ \\
& 0.5 & 3620 & 3541 & 079 & $2.18 \pm 0.12^{\mathrm{b}}$ & $(34)$ & $67 \pm 1.7$ & $33 \pm 1.7$ \\
& 2.0 & 4030 & 3964 & 066 & $1.64 \pm 0.04^{\mathrm{a}}$ & $(50)$ & $80 \pm 3.7$ & $20 \pm 3.7$ \\
& 0.0 & 4153 & 3966 & 187 & $4.50 \pm 0.16$ & & $56 \pm 1.2$ & $44 \pm 1.2$ \\
& 0.5 & 4860 & 4719 & 141 & $2.90 \pm 0.35^{\mathrm{a}}(36)$ & $75 \pm 0.7$ & $25 \pm 0.7$ \\
48 & 2.0 & 5230 & 5102 & 128 & $2.45 \pm 0.22^{\mathrm{a}}$ & $(46)$ & $66 \pm 0.1$ & $34 \pm 0.1$ \\
& 0.0 & 4342 & 4171 & 171 & $3.94 \pm 0.20$ & $54 \pm 2.4$ & $46 \pm 2.4$ \\
& 0.5 & 5672 & 5549 & 123 & $2.17 \pm 0.19^{\mathrm{a}}$ & $(45)$ & $72 \pm 3.2$ & $28 \pm 3.2$ \\
& 2.0 & 6622 & 6525 & 097 & $1.47 \pm 0.10^{\mathrm{a}}(63)$ & $75 \pm 1.6$ & $25 \pm 1.6$ \\
\hline
\end{tabular}

${ }^{\mathrm{a}}$ Significant at $p<0.001$ and $^{\mathrm{b}}$ at $p<0.012 \times 2$ contingency $\chi 2$ analysis compared to respective control. H, treatment hours; IN, inter phase cells; Con, control; P, prophase; M, metaphase; A, anaphase; T, telophase; $\sum \mathrm{DC}$, total number of dividing cells; TC, total number of cells counted; MI, Mitotic index ( $\left.\sum \mathrm{DC} / \mathrm{TCx} 100\right)$.

Table 3. Pooled data showing the influence of AESN on colchicine induced metaphase arrest frequency in Wistar rat bone marrow cells.

\begin{tabular}{ccccc}
\hline AESN (mg/kg) & Hours & $\begin{array}{c}\text { TM/TC } \\
\text { (No. of rats) }\end{array}$ & Range & MF\% \\
\cline { 3 - 5 } & & & & $\begin{array}{c}\text { Mean } \pm \text { SEM } \\
\% \text { reduction })\end{array}$ \\
\hline 0.00 & 15 & $826 / 19665(6)$ & $2.83-6.77$ & $4.32 \pm 0.72$ \\
100 & & $750 / 35583(6)$ & $1.23-2.76$ & $2.13 \pm 0.19^{\mathrm{a}}(50.7)$ \\
300 & & $365 / 32129(6)$ & $0.99-1.40$ & $1.16 \pm 0.07^{\mathrm{a}}(73.2)$ \\
500 & $311 / 37288(6)$ & $0.69-0.95$ & $0.84 \pm 0.03^{\mathrm{a}}(80.6)$ \\
\hline
\end{tabular}

${ }^{a}$ Significant at $p<0.0012 \times 2$ contingency $\chi 2$-test with respective control. TM; Total No. of Metaphase, TC; Total No. of cells scored, MF; Metaphase frequency.

Table 4. Different phytochemicals detected in AESN with the various conventional procedures

\begin{tabular}{llll}
\hline $\begin{array}{l}\text { Serial } \\
\text { No. }\end{array}$ & Phytochemicals & Tests performed & Results \\
\hline 1. & Alkaloids & Mayer's test & + \\
& & Wargner's test & + \\
& & Hager's test & + \\
& & Tannic acid test & + \\
2. & Flavonoids & Zinc hydrochloride test & - \\
& & Shinoda test & + \\
& & Alkaline solution test & + \\
3 & Anthraquinones & Siddique and Ali test & + \\
4 & Terpenoids & Borntrager's test & - \\
5. & Steroids & Kantamreddi et. al. 2010 & + \\
6. & Tannins & Fantamreddi et. al. 2010 & - \\
& & Bromine water test & + \\
& & Alkaline reagent test & + \\
7 & Phlobatannins & HCl test & + \\
8 & Saponins & Froth test & + \\
9 & Glycosides & Bromine water test & + \\
& & Fehling's test & - \\
& & Alkaline reagent test & - \\
10 & Carbohydrates & Benedict's test & - \\
& & Fehling's test & - \\
\hline & & & \\
& & & - \\
& & &
\end{tabular}




\section{DISCUSSION}

Synedrella nodiflora (L.) Gaertn. is a less known medicinal plant with several folk medicinal uses in different countries ${ }^{[8],[9]}$. The work presented herein focused on the antiproliferative activity of the AESN in onion root apical meristem and Wistar rat bone marrow cells. Moreover, the phytotoxic and antiproliferative effects of AESN were analysed by measuring the root (green gram and onion) and shoot growth retardation and the branch root sprouting inhibition in green gram seedlings.

In the initial experiments a wide range $(0.5$ to $6 \mathrm{mg} / \mathrm{ml})$ of AESN concentration was applied to determine $\mathrm{IC}_{50}$ and then 0.5 and $2 \mathrm{mg} / \mathrm{ml}$ of AESN was selected for mitodepression analysis in onion root apical meristem cells. In the present study, AESN $(0.5$ to $6 \mathrm{mg} / \mathrm{ml})$ treatment could induce dose dependent reduction in root and shoot length of green-gram seedlings. In green gram seedlings, the root growth retardation increased from 2 to $77 \%$ for the increased concentration from 0.5 to $6 \mathrm{mg} / \mathrm{ml}$ ( $\mathrm{p}<0.001$ ). Our previous study showed colchicine, a metaphase arresting agent, also induced growth retardation in green-gram seedlings in a dose dependent manner ${ }^{[26]}$. The present results indicate both root and shoot apical meristem cells are sensitive to AESN and also 100\% branch root sprouting inhibited with $6 \mathrm{mg} / \mathrm{ml}$ AESN treatment for $120 \mathrm{~h}$. In green gram seedlings, the lowest $\mathrm{IC}_{50}$ value, $2.82 \mathrm{mg} / \mathrm{ml}$ was recorded for branch root sprouting. This branch root sprouting inhibition may be due to its growth inhibitory activity, which further support the notion of its antiproliferative potentials. Fig. 3 clearly indicates onion root growth retardation and swelling phenomenon at the apical meristem region. These results are in agreement with the previous study reports indicating the root growth retardation is a result of the suppression of cell division ${ }^{[27]}$. A number of earlier studies have suggested that the level of root growth inhibition increases with the increasing extract concentrations ${ }^{[26],[28]}$.

For the antiproliferative activity analysis in onion root apical meristem cells, mitotic index depression and the alterations in the prophase-metaphase, and anaphase-telophase cumulative frequencies were scored. Mitotic index depression bioassays for antiproliferation revealed that AESN treatment could reduce the mitotic index significantly $(p<0.001)$ and reduced the cumulative frequencies of anaphase-telophase in treated onion root meristem cells as compared to the respective untreated controls (Table 2). This depression of mitotic index indicates distinct antiproliferative activity of AESN and this may be due to the interactions of the phytochemical ingredients with the cellular mitotic apparatus that lead to induced increased delay in interphase and that may be resulted in increased interphase cell frequency, interphase to mitotic phase transition block and decreased MI\%. Moreover, delayed cell cycle kinetics in the AESN treated onion root apical meristem mitotic cells may be explained by the increased cumulative frequency of prophase-metaphase and decreased cumulative frequency of anaphase-telophase. To the best of our knowledge, this is the first report showing the antiproliferative potentials of AESN. There are similar types of previous reports exist on mitotic index depression ${ }^{[29-31]}$. Ateeq et. al. ${ }^{[32]}$ reported a comparable observation with commercial herbicides like butachlor and pentachlorophenol, 2,4-D. Such a reduction in mitotic index suggests that exposure to AESN led to the cell cycle disturbances and decrease in cell number entering mitotic division. In the present and our previous study, onion root apical meristem cells were found to be excellent cell system for cell cycle kinetics analysis ${ }^{[26]}$. Levan first introduced A. cepa root tip assay and later it was used as a standard method to study genotoxicity ${ }^{[33-38]}$. Like dose dependent root and shoot growth retardation and reduction in branch root sprouting phenomenon in green gram seedlings and mitodepression in onion root apical meristem cells, the AESN has also influenced the cell cycle kinetics of WRBMCs. In vivo study with WRBMCs indicated the colchicine induced metaphase frequency reduction with the increasing doses of AESN treatment; indicating dose dependent induced delay in cell cycle kinetics. All the AESN treatment doses $(100,300$ and $500 \mathrm{mg} / \mathrm{kg}$ body weight) could induce cell cycle delay in interphase which may be the reason of reduced number of cells at mitotic phases, hence, less number of cells were available to be arrested at the metaphase with the colchicine actions. In an another study, similar antiproliferative effects of leaf aqueous extracts from a traditionally used medicinal plant (Clerodendrum viscosum), revealed antiproliferative, metaphase arresting and apoptosis inducing activities in both the plant and animal cell systems ${ }^{[26],[39]}$. Aqueous extract from the leaves of Toona sinensis has been shown to have an antiproliferative effect on human lung cancer cells ${ }^{[40],[41]}$. Some of the efficient anticancer and anti-neoplastic agents exert their effect through the cell cycle progression machinery ${ }^{[42]}$.

In the present investigation, the AESN was screened for 10 different types of phytochemicals and of these six were found to be present (Table 4). Study showed presence of alkaloids, flavonoids, terpenoids, tannins, phlobatannins and saponins while anthraquinones, steroids, glycosides and carbohydrates were found to be absent. Presence of triterpenes, alkaloids, flavonoids, phenols and saponins were in agreement with the earlier report ${ }^{[7]}$. The aqueous extract value was determined and which found to be quite high $(17.64 \%)$, indicating abundant water soluble components. Earlier, $S$ nodiflora extracted in petroleum ether, chloroform, acetone, methanol and water and then the extracts were subjected to TLC finger printing for characterization and 
it was shown that maximum contents were water soluble ${ }^{[9]}$. The present study indicates that the AESN contains bio-active allelochemicals which may interact with the mitotic apparatus. The secondary metabolites acting as allelochemicals include alkaloids, phenols and terpenoids. Phenols are the most abundant substances that affect seedlings growth and cell division ${ }^{[43]}$. The present study also demonstrates high quantity of phenolic components in AESN and that may be involved in antiproliferative activity. Our findings further support that the antiproliferative tests with the onion root apical meristem cells are correlated with in vivo test using WRBMCs and that was also earlier validated by using other animal cells ${ }^{[44],[45]}$. The medicinal properties of plants have been claimed to lie in their phytochemical ingredients which can produce a specific action on the human physiolog $y^{[46-51]}$. The efficient anticancer and anti-neoplastic agents exert their effect through the cell cycle progression machinery ${ }^{[42]}$. Others and our present study indicate the presence of bioactive compounds like alkaloid, flavonoids, terpenoids, tannins, phlobatannins and saponins in $\mathrm{AESN}^{[52]}$. Therefore, the present results indicate that AESN contains bio-active compound(s) that interact with the cell cycle components and the antiproliferative activity of AESN appears to explain the chemo-preventive or anticancer effects of its bioactive components like tannins, terpenoids and saponins. Thus, the novel findings of the present study are the exploration of chemopreventive pharmacological activities like antiproliferative and phytotoxic potentials of AESN.

\section{CONCLUSION}

From the above results, it may be concluded that, the AESN contains bioactive components which possess significant antiproliferative potential. Further investigations are in progress to isolate the active principle(s) and to determine their influence on the cell division regulatory gene expression.

\section{ACKNOWLEDGEMENT}

The authors gratefully acknowledge the financial support of the UGC, India and infrastructural supports of the Department of Zoology (DST-FIST and UGC-DRS Sponsored Department), The University of Burdwan, West Bengal, India.

\section{REFERENCES}

J.L. Figueroa-Hernandez, G.S. Gonzalez, V.J. Ascencio, J.L. Figueroa-Espitia and G.F. Saavedra, Plant products with anti-cancer properties employed in the treatment of bowel cancer: literature review 1985 and 2004, Proc. West Pharmacol. Soc., 48, 2005, 7783.

Y. Li., F. Shan, J.M. Wu, G.S. Wu, J. Ding, D. Xiao, W.Y. Yang, G. Atassi, S. Leonce, D.H. Caignard and P. Renard, Novel antitumor artemisinin derivatives targeting $\mathrm{G}_{1}$ phase of the cell cycle, Bioorg. Med. Chem. Lett., 11, 2002, 5-8.

[3.] J.M. Pezzuto, Plant-derived anticancer agents, Biochem. Pharm., 53, 1997, 121-133.

[4.] K.M. Sato, I. Mochizuki, Y.C. Saiki, K. Yoo, I. Samukawa and I. Azuma, Inhibition of tumor angiogenesis and metastasis by a saponin of Panax ginseng, ginsenoside-Rb2, Biol. Pharm. Bull., 17, 1994. 635-639.

[5.] G.M. Cragg, J.E. Simon, J.G. Jato and K.M. Snader, Drug discovery and development at the National Cancer Institute: potential for new pharmaceutical crops, En: Janick J. ed., Progress in New Crops, (Arlington, VA: ASHS Press. 1996) 554-560.

[6.] C. Wiart, Medicinal plants of the Asia-pacific: drugs for the future? (World Scientific, Kuala Lumpur , Malaysia. 2006 ) 635.

[7.] M.J. Rathi, S. Gopalkrishnan, Insecticidal activity of aerial parts of Synedrella nodiflora (L.) Gartn (Compositae) on Sapodeptera latura (FAB), J. cent. Eur. Agric., 6, 2005, 323-328.

[8.] M. Rahmatullah, A.A.B.T. Kabir, Md.M. Rahman, Md. S. Hossan, Z .Khatun, Mst. A. Khatun, R. Jahan, Ethnomedicinal practices among a minority group of Christians residing in Mirzapur Village of Dinajpur District, Bangladesh, Advances in Natural and Applied Sciences. 4(1), 2010, 45-51

[9.] P.Y. Bhogaonkar, M.J. Dagawal and D.S. Ghorpade. Pharmacognostic studies and antimicrobial activity of Synedrella nodiflora (L.) Gaertn., Bioscience Discovery, 2(3), 2011,317-321.

[10.] J.O. Olukunleand M.O. Abatan, The toxicological effects of aqueous leaf extract of Synedrella nodiflora in rats, ASSET Series B, 7(1), 2008, 81-89

[11.] M. Dutta , A.K. Nath, M.Z. Uddin, M.A. Hossain, M.M. Morshed and M.H. Kawsar, In vitro antioxidant, total phenolic content and brine shrimp lethality studies of Synedrella nodiflora. International Journal of Pharmaceutical Sciences and Research,, 3(5), 2012, 1528-1531.

[12.] N. Ghayal, A. Padhye and D. Kondiram, Larvicidal activity of invasive weeds Cassia uniflora and Synedrella nodiflora. International Journal of Pharma and Bio Sciences, 1(3), 2010, 245-249.

[13.] S. Wijaya, T.K. Nee, K.T. Jin, L.K. Hon, L.H. San and C. Wiart, Antibacterial and antioxidant activities of Synedrella nodiflora (L.) Gaertn. (Asteraceae), Journal of Complementary and Integrative Medicine, 8(1), 2011, 1-13.

[14.] R. Zahan, L. Nahar, A. Haque, A. Mosaddik, A. Fazal, Z. Alam and M.E. Haque, Antidiarrhoeal and hypoglycemic effects of Synedrella nodiflora, Phytopharmacology, 2(2), 2012, 257-264.

[15.] A. Haque, R. Zahan, L. Nahar, A. Mosaddik and E. Haque, Anti-inflammatory and insecticidal activities of Synedrella nodiflora, Molecular \& Clinical Pharmacology, 2(2), 2012, 60-67.

[16.] L. Greice, M.F. Juliana, D.L. Haywood, J.C.T. Paranhos, A.C.F. Silva and S.B. Tedesco, Extracts affecting mitotic division in roottip meristematic cells, Biologia, 63(5), 2008, 647-651.

[17.] A.K. Sharma and A. Sharma, Plant chromosomes: Analysis, manipulation and engineering, (Hardwood Academic Publishers, Amsterdam, Netherlands, 1999).

[18.] G.E. Trease and W.C. Evans, Pharmacognosy (Brailliar Tiridel can, $13^{\text {th }}$ ed. Macmillian Publishers, 1989).

[19.] A. Sofowara, Medicinal plants and Traditional medicine in Africa (Spectrum Books Ltd., Ibadan, Nigeria. 1993) pp.289.

[20.] J.B. Harborne, Phytochemical methods (Chapman and Hall, Ltd., London, 1973) 49-188.

[21.] A.A. Siddiqui and M. Ali, Practical Pharmaceutical chemistry (Ist ed. CBS publishers and distributors, New Delhi, India, 1997) 126-131. 
V.S.S.N. Kantamreddi, Y.N. Lakshmi and V.V.V.S. Kasapu, Preliminary phytochemical analysis of some important indian plant species, International Journal of Pharma and Bio Sciences, 1(4), 2010, 351-357.

H.O. Edeoga, D.E. Okwu and B.O. Mbaebie, Phytochemical constituents of some Nigerian medicinal plants, African Journal of Biotechnology, 4(7), 2005, 685-688.

H.P.S. Makkar, M. Blummel, N.K. Borowy and K. Becker, Gravimetric determination of tannins and their correlations with chemical and protein precipitation methods, J. Sci. Food Agric., 61, 1993, 161-165.

D.J. Finney, Probit Analysis ( $2^{\text {nd }}$ ed, Cambridge University Press, Cambridge, England, 1952).

S. Ray, L.M.Kundu, S. Goswami, G.C. Roy, S. Chatterjee, S. Dutta, A. Chaudhuri and C.S. Chakrabarti, Metaphase arrest and delay in cell cycle kinetics of root apical meristems and mouse bone marrow cells treated with leaf aqueous extract of Clerodendrum viscosum Vent., Cell Prolif., 46, 2013, 109-117.

G. Fiskesjo, The Allium tests as a standard in environmental monitoring, Hereditas, 102, 1985, 99-112.

G.S. Murthy, T.P. Francis, C.R. Singh, H.G. Nagendra and C. Naik, An assay for screening anti-mitotic activity of herbal extracts, Current Science, 100(9), 2011, 1399-1404.

S.A. Ashourand R.F. Abdou: The action of igran, topograd and eptam herbicides on germination, seedling growth and mitotic behaviour of faba bean (Vicia faba L.) FABIS., Newsletter, 26, 1990, 10-14.

A.Z.E. Salam, E.H.A. Hussein, H.A. El-Itriby, W.A. Anwer and S.A. Mansour, The mutagenicity of gramoxone (paraquat) on different eukaryotic systems, Mut. Res., 319, 1993, 89-101.

A.Z.E. Salam, K.H.A. Soliman, H.Z. Hassan, Mutagenic potentialities of two organophosphorus compounds using different biological systems, Egyptian J. Genet. Cytol., 26, 1997,. 105-120.

B. Ateeq, M.A. Farah, M.N. Ali and W. Ahmad, Clastogenicity of pentachlorophenol, 2,4-D and butachlor evaluated by Allium root tip test, Mutat. Res., 514, 2002, 105-113.

A. Levan, The effect of colchicine on root mitosis in Allium., Hereditas, 24, 1938, 471-486.

J. Angayarkanni, K.M. Ramkumar, T. Poornima and U. Priyadarshini, Cytotoxic activity of Amorphophallus paeoniifolius tuber extracts in vitro, American Eurasian J. Agric. \& Environ. Sci., 2(4), 2007, 395-398.

J.M. Fachinetto, M.D. Bagatini, J. Durigon, A.C.F. Silva and S.B. Tedesco, Anti-proliferative effect of infusions of Achyrocline satureioides on the Allium cepa cell cycle, Rev. Bras. Farmacogn., 17, 2007, 49-54.

G. Fiskesjo, Allium test on river water from bran and sexan before and after closure of a chemical factory, Ambiologia, 14, 1985, 99-103.

R. Carita and M.A. Marin-Morales, Induction of chromosome aberrations in the Allium cepa test system caused by the exposure of seeds to industrial effluents contaminated with azo dyes, Chemosphere, 72, 2008, 722-725.

D.M. Leme and M.A. Marin-Morales, Allium cepa test in environmental monitoring: a review on its application, Mutat. Res., 82, 2009, 71-81.

S. Ray, L.M. Kundu, S. Goswami, C.S. Chakrabarti, Antiproliferative and apoptosis inducing activity of allelochemicals present in leaf aqueous extract of traditionally used antitumor medicinal plant, Clerodendrum viscosum vent., International Journal of Pharmaceutical Research and Development, 4(06), 2012, 332-345.

C. Laosinwattana, W. Phuwiwat and P. Charoenying, Assessment of allelopathic potential of Vetivergrass (Vetiveria sp.) ecotypes, Allelopathy J., 19, 2007, 469-478.

C. Laosinwattana, T. Poonpaiboonpipat, M. Teererak, W. Phuwiwat, T. Mongkolaussavaratanaand P. Charoenying, Allelopathic potential of Chinese rice flower (Aglaia odorata Lour.) as organic herbicide, Allelopathy J., 24, 2009, 45-54.

Y. Li, F. Shan, J.M. Wu, G.S. Wu, J. Ding, D. Xiao, W.Y. Yang, G. Atassi, S. Leonce, D.H. Caignardand P. Renard, Novel antitumor artemisinin derivatives targeting $\mathrm{G}_{1}$ phase of the cell cycle, Bioorg. Med. Chem. Lett., 11, 2002, 5-8.

M.A.K. Lodhi, Role of allelopathy as expressed by dominating trees in a low land forest in controlling the productivity and pattern of herbaceous growth, J. Bot., 63, 1976, 1-8.

L.K.S. Chauhan, P.M. Saxena and S.K. Gupta, Cytogenetics effects of cypermethrin and fenvalerate on the root meristem cells of A. cepa., Environment and Experiment Botany, 42, 1999, 181-189.

V.E.P. Vicentini, M.L. Camparoto, R.O. Teixeira and M.S. Mantovani, Averrhoa carambola (L.), Syzygium cumini (L.) Skeels and Cissus sicyoides (L.): medicinal herbal tea effects on vegetal and test systems, Acta. Scientiarum, 23, 2001, 593-598.

T.T. Phan, L. Wang, P. See, R.J. Grayer, S.Y. Chan and S.T. Lee, Phenolic compounds of Chromolaena odorata protect cultured skin cells from oxidative damage: implication for cutaneous wound healing, Biol. Pharm. Bull., 24, 2001, 1373-1379.

K.M. Sato, I. Mochizuki, Y.C. Saiki, K. Yoo, I. Samukawa and I. Azuma, Inhibition of tumor angiogenesis and metastasis by a saponins of Panax ginseng, ginsenoside-Rb2, Biol. Pharm. Bull,. 17, 1994, 635-639.

C.H. Nepka, E. Asprodini and D. Kouretas, Tannins, xenobiotic metabolism and cancer chemoprevention in experimental animals, Eur. J. Drug. Metab. Ph., 24(2), 1999, 183-189.

K.T. Liby, M.M. Yore and M.B. Sporn, Triterpenoids and retinoid as multifunctional agents for the prevention and treatment of cancer, Nat. Rev. Cancer., 7, 2007, 357-369.

Z. Ovesna, A. Vachalkova, K. Horvathova and D. Tothova, Pentacyclic triterpenoic acids: new chemoprotective compounds, Minireview, Neoplasma, 51, 2007, 327-333.

M. Shoeb, Anticancer agents from medicinal plants, Bangladesh J. Pharmacol, 1, 2006, 35-41.

M.Z. Haque, M.A. Rouf, M.A. Jalil, B.M. Islam and M.R. Islam, Screening of phytochemical and biological potential of Clerodendron viscosum leaves extracts, Bangladesh J. Sci. Ind. Res., 45(4), 2010, 381-386.

(Data for figure 2.)

Table S1. Effects of AESN on onion root growth.

\begin{tabular}{llllll}
\hline $\begin{array}{l}\text { Dose } \\
(\mathrm{mg} / \mathrm{ml})\end{array}$ & No. of roots & $\begin{array}{l}\text { RLBT } \\
(24 \mathrm{~h} \text { aged })\end{array}$ & $\begin{array}{l}\text { RLAT } \\
(24 \mathrm{~h})\end{array}$ & $\begin{array}{l}\text { RLAT } \\
(48 \mathrm{~h})\end{array}$ & $\begin{array}{l}\text { Growth inhibition\% at } \\
48 \mathrm{~h}\end{array}$ \\
\hline 0.0 & 40 & $0.72 \pm 0.03$ & $2.42 \pm 0.13$ & $3.26 \pm 0.11$ & 00.0 \\
0.5 & 39 & $0.73 \pm 0.07$ & $1.27 \pm 0.12^{\mathrm{c}}$ & $1.61 \pm 0.15^{\mathrm{c}}$ & 65.4 \\
1.0 & 35 & $0.81 \pm 0.07$ & $1.06 \pm 0.13^{\mathrm{c}}$ & $1.25 \pm 0.14^{\mathrm{c}}$ & 82.7 \\
2.0 & 37 & $0.56 \pm 0.06$ & $0.75 \pm 0.06^{\mathrm{c}}$ & $0.90 \pm 0.06^{\mathrm{c}}$ & 86.7 \\
4.0 & 36 & $0.62 \pm 0.07$ & $0.76 \pm 0.09^{\mathrm{c}}$ & $0.86 \pm 0.13^{\mathrm{c}}$ & 90.6 \\
6.0 & 36 & $0.61 \pm 0.06$ & $0.65 \pm 0.06^{\mathrm{c}}$ & $0.71 \pm 0.06^{\mathrm{c}}$ & 96.1 \\
\hline
\end{tabular}

${ }^{\mathrm{c}}$ Significant at $p<0.001$ Student's t-test analysis compared to untreated control. RLBT; root length before treatment, RLAT; root length after treatment 